\title{
Triage in an adult emergency service: patient satisfaction
}

\author{
Acolhimento com classificação de risco do serviço de \\ pronto-socorro adulto: satisfação do usuário \\ Acogida con clasificación de riesgo del servicio de urgencias \\ adulto: satisfacción del usuario
}

\author{
Pollyane Liliane Silva ${ }^{1}$, Luciana Paiva², Veridiana Bernardes Faria' ${ }^{1}$, Rosali Isabel Barduchi Ohl ${ }^{3}$, Suzel Regina Ribeiro \\ Chavaglia ${ }^{1}$
}

How to cite this article:

Silva PL, Paiva L, Faria VB, OhI RIB, Chavaglia SRR. Triage in an adult emergency service: patient satisfaction. Rev Esc Enferm USP. 2016;50(3):427-432. DOI: http://dx.doi.org/10.1590/S0080-623420160000400008

${ }^{1}$ Universidade Federal do Triângulo Mineiro, Uberaba, MG, Brazil.

${ }^{2}$ Universidade Federal do Triângulo Mineiro, Hospital de Clínicas, Uberaba, MG, Brazil.

${ }^{3}$ Universidade Federal de São Paulo, Escola Paulista de Enfermagem, São Paulo, SP, Brazil

\begin{abstract}
Objective: Assess the degree of patient satisfaction with triage in the adult emergency service of a public hospital. Method: Exploratory, descriptive, cross-sectional study with a quantitative approach. Three hundred patients were interviewed and the data were analyzed using descriptive statistics based on sociodemographic variables and those related to patient satisfaction. Results: There was a predominance of women, with elementary education and a mean age of 41 years. Most of the interviewees reported being satisfied in regard to the following items: timely service, embracement, trust, environment (comfort, cleanliness and signage), humanization (courtesy, respect, and interest), timely referral/scheduling of appointments and care expectations. Conclusion: There was a high level of patient satisfaction, evidenced by the strong association of user satisfaction with the items investigated.
\end{abstract}

DESCRIPTORS

Patient Satisfaction; Emergency Medical Services; Health Services Administration; Quality of Health Care; Emergency Nursing.
Corresponding author:

Rosali Isabel Barduchi Ohl

Rua Napoleão de Barros, 754 - Vila Clementino

CEP 04024-002 - São Paulo, SP, Brazil

rosaliohl@hotmail.com
Received: 07/15/2015

Approved: 05/05/2016 


\section{INTRODUCTION}

The Ministry of Health has been investing in the humanization of health services since the start of the $21^{\text {st }}$ century. Triage is one of the methodologies used to prioritize the order of care given in emergency units, which seeks to: assess patients upon arrival; humanize care; decongest hospital services; reduce waiting time to see a physician; establish the areas of primary care, so that patients are directly referred to the necessary specialty; inform waiting time and provide family members with information ${ }^{(1)}$.

The worsening of a sickness that has already set in leads patients to seek secondary and/or tertiary levels of care, such as emergency units, since these services provide more timely care and effective resolution of the health issue. Therefore, these units are ideal for serving people's health needs, via specialized medical visits, diagnostic tests, high-cost procedures and hospitalization ${ }^{(2)}$.

At the same time, they provide easy and assured access, care and highly complex technology, receiving and attending to emergency situations not dealt with at the primary health care level. Therefore, these services are typically overcrowded and noted for impersonal treatment, only focusing on the main complaint of the individual ${ }^{(3)}$.

In 2004, the Ministry of Health published a primer on the National Policy for Humanization of Care and Management of the Unified Health System, which defines triage as a strategy for transforming work activities in health care and production, particularly in emergency units ${ }^{(4)}$.

It is precisely in terms of action characterized as being with or close to that triage is one of the most relevant political, ethical and aesthetic guidelines of this policy. It stresses the importance of clearly explaining to patients that the prioritization of care in the emergency unit will be based on the triage assessment, so that medical care can be dynamic and effective, and lead to greater patient satisfaction ${ }^{(4-5)}$.

Triage entails receiving patients, upon their arrival, taking full responsibility for them, listening to their medical complaints, worries and distress, ensuring effective resolution of the problem and interaction with other health services for continued care when necessary ${ }^{(6)}$.

In emergency situations, triage is a tool used to establish priority of care according to the seriousness of each case. In this method, triage is performed by a trained nurse, using internationally established protocols ${ }^{(6)}$.

The authors of this study believe that the person best suited to perform triage in emergency units is the nurse. To do so, a protocol must be used to guide their actions. Among the existing scales and protocols for this purpose, there is the U.S. scale Emergency Severity Index (ESI), the Australian scale Australasian Triage Scale (ATS), the Canadian protocol Canadian Triage and Acuity Scale $\left(\mathrm{CTAS}^{\odot}\right)$ and the British protocol Manchester Triage System $\left(\mathrm{MTS}^{\odot}\right)$, also referred to as the Manchester protocol ${ }^{(7-8)}$.

It is known that the Manchester protocol is used in many countries and that a group of Brazilian experts assessed the protocol in terms of the feasibility of adapting it to the Brazilian reality. In Brazil, the state of Minas Gerais was the pioneer in using the Manchester Triage System, which was adopted as a public policy in $2008^{(9)}$.

The Manchester Triage System protocol is a work methodology that was developed in Britain in the 1990s. It was initially implemented in the city of Manchester in 1997, after which it was adopted as the standard for hospitals in the United Kingdom. It was also either adopted or being implemented in Ireland, Holland and Canada ${ }^{(10)}$.

The purpose of this protocol is to classify patients according to priority of intervention. The steps of the method are the following: identify the patient's initial complaint, follow the decision flowchart and, last, establish the waiting time according to severity.

The flowchart establishes the order in which patients will be seen on the basis of a color system, where red (emergency) requires immediate care; orange (very urgent) sets a maximum waiting time of ten minutes; yellow (urgent), 60 minutes; green (standard), 120 minutes; and blue (non-urgent), 240 minutes. Organization of medical care by classification of risk enables more effective and timely care ${ }^{(11-12)}$.

Through assessment of health services, it is possible to determine the efficiency, efficacy and effectiveness of the structures, processes and outcomes related to access and patient satisfaction with public health services. Evaluation is an essential part in the planning and management of the health system, to achieve quality and effective resolution of patients' problems.

Triage in emergency departments is a complex activity that depends on the skills and competencies of nurses as well as external and subjective factors, such as the work environment, interpersonal relationships and communication. There is a study which indicates the need for training nurses in triage, since it was observed that the greater the professional qualification and the higher the number of hours performing triage, the more reliable the results in prioritization of care ${ }^{(13)}$.

In this regard, the literature points out that health professionals working in emergency units need to develop skills that ensure technical and scientific competence as well as an embracing and humanized approach toward patients ${ }^{(5,14)}$.

Triage in Brazil in the process of being built and implemented and is part of the Humaniza SUS proposal (Humanize the Unified Health Service). Therefore, it needs to be continuously assessed and improved. It should be noted that there are few studies addressing this issue. Patient satisfaction is extremely important, since some studies indicate that satisfied patients tend to adhere to the prescribed treatment, provide important information for professionals and continue using health services, in addition to improving their quality life ${ }^{(15-17)}$.

In this regard, it is essential to know how patients judge and understand the triage process, in order to reevaluate health practices and provide input for changes in organizing the service.

In light of these questions, the objective of this study was to assess the degree of satisfaction of patients with triage in the adult emergency unit of Hospital das Clínicas at Universidade Federal do Triângulo Mineiro (HC/UFTM) in relation to the criteria: trust in the health team, indications of humanization (courtesy, respect and interest), environment 
(comfort, cleanliness and signage), timely care and referral or scheduling of appointments.

\section{METHOD}

This is an exploratory, descriptive, cross-sectional study, with a quantitative methodological approach. The study site was the triage sector of an adult emergency unit ( $\mathrm{HC} /$ UFTM). This hospital is classified and authorized to provide tertiary care, carry out high-complexity procedures, such as organ recruitment and removal, kidney and cornea transplants, kidney transplant therapy, orthopedic, ophthalmology and oncology treatments, neurosurgery and emergencies, serving residents from the city of Uberaba and the Triângulo Mineiro region ${ }^{(18-19)}$.

The study project was approved by the Human Research Ethics Committee of UFTM, under Protocol No. $1569 / 2009$. Data were collected from the subjects after they received an explanation regarding voluntary participation and assurances of confidentiality and anonymity, and after signing a free and informed consent form.

The sample was calculated according to the regulatory standards of the Ministry of Health ${ }^{(18)}$, which requires patient satisfaction surveys to be performed using a sample calculation based on the mean number of patients seen by the establishment in the last ten months. This calculation can range from $1 \%$ to $100 \%$ depending on the size of the service.

Thus, 300 patients from the triage sector of the adult emergency unit (HC/UFTM) were interviewed. The inclusion criteria were: having sufficient age, preferably 18 or over, being assisted to in the triage sector, being classified as yellow, green or blue, i.e., not presenting a serious risk condition or imminent risk of death, agreeing to participate in the study, having been duly informed, and signing the free and informed consent form.

The sociodemographic variables were: gender, age group, education and medical specialty. The variables related to patient satisfaction were: waiting time to see a physician, health team (courtesy, respect, interest and trust), garments provided by the health service, care provided, care expectations and physical environment (signage, comfort and cleanliness).

Data collection was performed using a form proposed by the Ministry of Health ${ }^{(18)}$, adapted by the researchers of this study. The items were comprised of a series of 11 questions, divided into primary and secondary questions, to make it easier for interviewees to understand. The data were collected during the morning, afternoon and evening periods, according to the hours of operation of the sector, after triage was performed, in interviews lasting around ten minutes each.

The collected data were entered into an electronic spreadsheet, with the double entry technique. The data were analyzed by means of simple descriptive statistics, frequency, percentage and mean, median and mode central tendencies, by means of the EPI INFO (TM) 3.4.3 program.

\section{RESULTS}

In the sociodemographic profile of the patients, of the 300 subjects interviewed, there was a predominance of women $(169-56.3 \%)$. The age range was from 13 to 92 years, with a mean age of 41 , median age of 37.5 and mode of 25 years. Most of the patients in the triage sector of the adult emergency unit (HC/UFTM) had a low educational level, with a predominance of patients $(182-60.7 \%)$ with complete elementary school.

Table 1 - Distribution of patients in numbers and percentages according to gender, age group and education, adult emergency unit, HC/UFTM - Uberaba, MG, Brazil, 2014.

\begin{tabular}{|c|c|c|}
\hline \multirow{2}{*}{ Variable } & \multicolumn{2}{|c|}{ User } \\
\hline & $\mathbf{n}$ & $\%$ \\
\hline \multicolumn{3}{|l|}{ Gender } \\
\hline Female & 169 & 56.6 \\
\hline Male & 131 & 43.7 \\
\hline \multicolumn{3}{|l|}{ Age } \\
\hline$\leq 20$ & 23 & 7.7 \\
\hline $21-30$ & 89 & 29.6 \\
\hline $31-40$ & 48 & 16.3 \\
\hline $41-50$ & 47 & 15.6 \\
\hline $51-60$ & 47 & 15.6 \\
\hline $61-70$ & 32 & 10.7 \\
\hline $71-80$ & 07 & 2.2 \\
\hline$\geq 81$ & 07 & 2.2 \\
\hline \multicolumn{3}{|l|}{ Education } \\
\hline Illiterate & 23 & 7.7 \\
\hline Incomplete elementary & 94 & 31.3 \\
\hline Complete elementary & 65 & 21.7 \\
\hline Incomplete secondary & 95 & 31.7 \\
\hline Undergraduate degree & 22 & 7.3 \\
\hline Graduate degree & 01 & 0.3 \\
\hline Total & 300 & 100 \\
\hline
\end{tabular}

Patients from the triage sector with a risk classification are referred to the different medical specialties, with a predominance of care in internal medicine $(114-38 \%)$, followed by: surgical ( $86-28.7 \%)$, gynecology and obstetrics $(46-15.3 \%)$, orthopedic $(28-9.3 \%)$ and other specialties $(26-8.6 \%)$.

The variables related to patient satisfaction with the care provided were: waiting time, health team (courtesy, respect, interest and trust), garments provided by the health service, care provided and physical environment (signage, comfort and cleanliness).

Most patients $(261-87 \%)$ expressed satisfaction with the service in regard to waiting time to be seen by a physician. The responses for the courtesy, respect, interest and trust factors in relation to the health team indicated that practically all the patients $(296-98.7 \%)$ were satisfied with the care, with "trust in the team" being the highest scoring variable (192 users - 92\%). In terms of garments provided by the health establishment, most of the subjects were satisfied $(283-94.3 \%)$, particularly in regard to the cleanliness and comfort of the garments (Table 2). 
Table 2 - Data from the patient satisfaction variables in relation to triage in the adult emergency unit, HC/UFTM - Uberaba, MG, Brazil, 2014.

\begin{tabular}{lcccc}
\hline Satisfaction Variables & $\begin{array}{c}\text { Very Satisfied } \\
\mathbf{n}(\%)\end{array}$ & $\begin{array}{c}\text { Satisfied } \\
\mathbf{n}(\%)\end{array}$ & $\begin{array}{c}\text { Dissatisfied } \\
\mathbf{n}(\%)\end{array}$ & $\begin{array}{c}\text { Very Dissatisfied } \\
\mathbf{n}(\%)\end{array}$ \\
\hline Waiting Time & $51(17)$ & $210(70)$ & $35(11.7)$ & $4(1.3)$ \\
Health Team (courtesy, respect, interest and trust) & $81(27)$ & $215(71.7)$ & $3(1.3)$ & $0(00)$ \\
Garments supplied by the health service & $0(00)$ & $283(94.3)$ & $17(5.7)$ & $0(00)$ \\
\hline
\end{tabular}

As far as the care provided, most of the patients (219 - 73\%) reported having received information and explanations about their health status. With respect to knowing the name of the health professional who saw them, 259 (86.3\%) patients recognized the names of the professionals.

Most of the interviewees $(222-74 \%)$ claimed to know about the place responsible for complaints, in the event of unsatisfactory care. However, most of the patients $(222-$ $74 \%)$ said they did not know exactly how to file care complaints, as opposed to 78 (26\%) who knew where and how to register complaints about inadequate care.

In terms of the care expectation variable, 141 users (47\%) said their expectations matched the reality, 105 (35\%) reported it being better than expected and only 10 (3.3\%) expressed dissatisfaction, deeming the care to be worse than they had imagined.

As far as the physical environment, the majority of the patients 197 (65.7\%) considered the signage in the health service to be good. This aspect is important since it facilitates getting to the necessary locations. Worth noting, however, is that $48(16 \%)$ of the patients reported not having noticed the signage in the hospital.

Comfort in the environment was considered satisfactory by most of the patients $(217-72.4 \%)$, with $83(27.7 \%)$ participants expressing some degree of dissatisfaction. Another factor identified, which denotes satisfaction with quality of care, is cleanliness of the physical environment, an aspect evaluated positively by $272(90.7 \%)$ patients (Table 3 ).

Table 3 - Data on the variable related to the environment, comfort and cleanliness of the health service, adult emergency unit - HC/ UFTM - Uberaba, MG, Brazil, 2014.

\begin{tabular}{lccccc}
\hline Environment & $\begin{array}{c}\text { Very good } \\
\mathbf{n}(\%)\end{array}$ & $\begin{array}{c}\text { Good } \\
\mathbf{n}(\%)\end{array}$ & $\begin{array}{c}\text { Average } \\
\mathbf{n}(\%)\end{array}$ & $\begin{array}{c}\text { Poor } \\
\mathbf{n}(\%)\end{array}$ & $\begin{array}{c}\text { Very poor } \\
\mathbf{n}(\%)\end{array}$ \\
\hline Cleanliness & $90(30)$ & $182(60.7)$ & $28(9.3)$ & $0(00)$ & $0(00)$ \\
Comfort & $35(11.7)$ & $182(60.7)$ & $54(18)$ & $23(7.7)$ & $6(1.9)$ \\
\hline
\end{tabular}

\section{DISCUSSION}

The building of public health policies in recent decades has emphasized the need to implement good health practices aimed at providing comprehensive care. In this regard, triage helps enhance care in health facilities.

Triage methodology is a tool for improving the quality of emergency services, which enables and encourages positive changes in health practices. The Ministry of Health recommends its implementation in emergency units in the Unified Health System, to improve quality of care and comply with the humanization policy in health services. It also favors the participation and involvement of managers, workers and patients, thus contributing to a fairer and more equitable service provided to the population ${ }^{(20)}$.

A study on the assessment of the care process in emergency units noted the need for reorganizing health services, in terms of emphasizing the importance of the patient in the health care system, through the implementation of triage ${ }^{(21)}$.

The measurement of patient satisfaction with the health service is an important indicator of health service quality. In Brazil, from the second half of the 1990s, this indicator has been associated with the strengthening of community participation in the planning and assessment processes of public services. Studies were found in which patient satisfaction is associated with adherence to treatment and use of health services ${ }^{(16,22-24)}$.
In this study, it was noted that most patients were seen in the internal medicine, surgery and orthopedic departments. This reflects the current epidemiological transition in Brazil today, indicating the replacement of cases of communicable with noncommunicable diseases and external causes, the shifting of morbidity and mortality from younger age groups to older age groups, and prevalence of morbidity ${ }^{(25)}$.

There were high patient satisfaction rates as seen in the scores classified as "very good" and "good" for the variables surveyed among patients from the triage sector of the adult emergency unit (HC/UFTM). It can be inferred through the data that these high rates may be linked to the fact that this is a highly regarded tertiary care public hospital in the region, where the patients, mostly young and with a low level of education, are ensured to receive health care, with a higher probability that their health problems will be effectively resolved.

On the other hand, these patients may have expressed satisfaction with the services out of fear of losing access to care, since negative responses could suggest a conflictive interaction between patient and professional ${ }^{(17,26-27)}$.

In this regard, it is important to underscore the fact that there was a predominance of users with low education, since data observed in similar research indicate that this is a factor that has a strong influence on patient satisfaction with health institutions ${ }^{(28-30)}$.

These studies also show that the level of education has a direct effect on patient satisfaction with health services, 
which may represent a limitation in this study, since it is known that the higher the educational level, the higher the critical tendency of the patient toward the services provided and the higher the level of quality demanded of these services which, consequently, is more likely to cause dissatisfaction on the part of this population ${ }^{(31-32)}$.

As far as the variables of courtesy and respect of the health team, deemed by patients as satisfactory, there were similar data in the literature indicating satisfaction with the team's behavior during triage ${ }^{(28,32)}$.

Therefore, it can be inferred that effective communication and the relationship established with the members of the health team are key factors for people's satisfaction with these services. Care given with technical competence, combined with good patient interaction, on the part of health professionals, can ensure the provision of effective quality care.

Another aspect that must be considered is trust in the service, evaluated positively by the interviewees, as a factor that can strengthen adherence to treatment and recovery of the individual's health. Studies note that trust is an essential element for establishing the therapeutic relationship and has an important impact on adherence to treatment. Trust is considered as a reflection of the ability of a health service to carry out actions beneficial to patients, by assuring safety and quality of care c(28,30,32). $^{\text {. }}$

\section{CONCLUSION}

Knowing the opinions and expectations of people during triage is an important element in the evaluation of health services. In this regard, this study found that there was a high degree of satisfaction of these subjects mainly in relation to the variables: courtesy, respect, interest and trust shown by the health team and cleanliness and signage in the hospital environment.

Among the negative aspects pointed out by the population was the lack of comfort of the environment. The authors of this study believe that these elements are essential when it comes to health care, because they lead to effective resolution of the health issue and satisfying the needs of patients.

It was also noted that those who received more information when arriving in the emergency unit in regard to how the triage sector operates, expressed greater satisfaction with the service. These data support the conclusion that efficient use of health communication and information strategies within emergency units of the Unified Health System can have a significant bearing on patient satisfaction with the service provided.

There is clearly a need for the subject of patient satisfaction in relation to services provided in other care environments to be further explored in order to better establish the priorities in caring for people's health, as well as schedule actions that will lead to improvements in this area.

\section{RESUMO}

Objetivo: Avaliar o grau de satisfação dos usuários no setor de Acolhimento com Classificação de Risco do Pronto-Socorro Adulto de um hospital público. Método: Pesquisa exploratória, descritiva e transversal com abordagem quantitativa. Foram entrevistados 300 usuários e os dados foram analisados por meio de estatística descritiva a partir de variáveis sociodemográficas e as relacionadas à satisfação do usuário. Resultados: Houve predominância do sexo feminino, nível de escolaridade fundamental e idade média de 41 anos. A maioria dos entrevistados respondeu estar satisfeito em relação aos itens: agilidade no atendimento; acolhimento; confiança; ambiência (conforto, limpeza, sinalização), humanização (educação, respeito e interesse); agilidade no encaminhamento/agendamento de consulta e expectativa sobre o serviço. Conclusão: Verificou-se elevado grau de satisfação dos usuários, evidenciada pela forte associação da satisfação do usuário com os itens investigados.

\section{DESCRITORES}

Satisfação do Paciente; Serviços Médicos de Emergência; Administração de Serviços de Saúde; Qualidade da Assistência à Saúde; Enfermagem em Emergência.

\section{RESUMEN}

Objetivo: Evaluar el grado de satisfacción de los usuarios en el sector de Acogida con Clasificación de Riesgo del Servicio de Urgencias Adulto de un hospital público. Método: Investigación exploratoria, descriptiva y transversal con abordaje cuantitativo. Fueron entrevistados 300 usuarios y los datos fueron analizados por medio de estadística descriptiva a partir de variables sociodemográficas y las relacionadas con la satisfacción del usuario. Resultados: Hubo predominancia del sexo femenino, nivel de escolaridad básico y edad media de 41 años. La mayoría de los entrevistados respondió estar satisfecho con relación a los elementos: agilidad en la atención; acogida; confianza; entorno (confort, limpieza, señalización), humanización (educación, respeto e interés); agilidad en la derivación/programación de consulta y expectación sobre el servicio. Conclusión: Se verificó elevado grado de satisfacción de los usuarios, evidenciada por la fuerte asociación de la satisfacción del usuario con los elementos investigados.

\section{DESCRIPTORES}

Satisfacción del Paciente; Servicios Médicos de Emergencia; Administración de los Servicios de Salud; Calidad de la Atención de Salud; Enfermería de Urgencia.

\section{REFERENCES}

1. Brasil. Ministério da Saúde; Secretaria de Atenção à Saúde, Departamento de Ações Programáticas e Estratégicas. Política Nacional de Normalização. Atenção hospitalar. Brasília: MS; 2013.

2. Inoue KC, Bellucci Júnior JA, Papa MAF, Vidor RC, Matsuda LM. Evaluation of quality of Risk Classification in Emergency Services. Acta Paul Enferm. 2015;28(5):420-25. 
3. Souza CC, Mata LRF, Carvalho EC, Chianca TCM. Nursing diagnoses in patients classified as priority level I and II according to the Manchester protocol. Rev Esc Enferm USP. 2013;47(6):1318-24

4. Oliveira GN, Vancini-Campanharo CR, Okuno MFP, Batista REA. Nursing care based on risk assessment and classification: agreement between nurses and the institutional protocol. Rev Latino Am Enfermagem [Internet]. 2013 [citado 2015 jan.18]; 21(2). Disponivel em: http://www.scielo.br/pdf/rlae/v21n2/pt_0104-1169-rlae-21-02-0500.pdf

5. Paixão TCR, Campanharo CRV, Lopes MCBT, Okuno MFP, Batista REA. Nursing staff sizing in the emergency room of a university hospital. Rev Esc Enferm USP. 2015;49(3):481-7.

6. Gibaut MAM, Hori LMR, Freitas KS, Mussi FC Comfort of the patient's family in an Intensive Care Unit related to welcoming. Rev Esc Enferm USP. 2013;47(5):1117-24

7. Parentia N, Reggianib MLB, Primiano I, Percudanid D, Dowdinge D. A systematic review on the validity and reliability of an emergency department triage scale, the Manchester Triage System. Int J Nurs Stud. 2014;51(7):1062-9.

8. Cavalcante RB, Rates HF, Silva LTC, Mello RA, Dayrrel KMB. Acolhimento com classificação de risco: proposta de humanização nos serviços de urgência. Rev Enferm Cent O Min. 2012;2(3):428-37.

9. Torres FSF, Belisário AS, Melo EM. A Rede de Urgência e Emergência da Macrorregião Norte de Minas Gerais: um estudo de caso. Saúde Soc. 2015;24(1):361-73.

10. Azeredo TRM, Guedes HM, Almeida RAR, Chianca TCM, Martins JCA. Efficacy of the Manchester Triage System: a systematic review. Int J Nurs. 2015;23(2):47-52.

11. Guedes HM, Almeida AGP, Ferreira FO, Vieira Júnior G, Chianca TCM. Risk classification: portrait of a population using a Brazilian emergency service. Rev Enf Ref. 2014;4(1):37-44.

12. Pinto Júnior D, Salgado PO, Chianca TCM. Predictive validity of the Manchester Triage System: evaluation of outcomes of patients admitted to an emergency department Rev Latino Am Enfermagem [Internet]. 2012 [citado 2015 jan. 18];20(6). Disponível em: http://www.scielo. br/pdf/rlae/v20n6/pt_05.pdf

13. Silva MFN, Oliveira GN, Pergola-Marconato AM, Marconato RS, Bargas EB, Araujo IEM. Assessment and risk classification protocol for patients in emergency units Rev Latino Am Enfermagem. 2014;22(2):218-25.

14. Bellucci Júnior JA, Vituri DW, Versa GLGS, Furuya OS, Vidor RC, Matsuda LM. Acolhimento com classificação de risco em serviço hospitalar de emergência: avaliação do processo de atendimento. Rev Enferm UERJ. 2015;23(1)82-7.

15. Inoue KC, Murassaki ACY, Bellucci Júnior JA, Rossi RM, Martinez YDÉ, Matsuda LM. Acolhimento com Classificação de Risco: avaliação da estrutura, processo e resultado. REME Rev Min Enferm. 2015;19(1):13-20.

16. Paiva MBP, Mendes W, Brandão AL, Campos CEA. Uma contribuição para a avaliação da Atenção Primária à Saúde pela perspectiva do usuário. Physis Rev Saúde Coletiva. 2015;25(3):925-50.

17. Pena MM, Melleiro MM. Degree of satisfaction of users of a private hospital. Acta Paul Enferm. 2012;25(2):197-203.

18. Brasil. Ministério da Saúde; Secretaria Executiva, Departamento de Regulação, Avaliação e Controle de Sistemas. PNASS: Programa Nacional de Avaliação de Serviços de Saúde. Brasília: MS; 2015.

19. Universidade Federal do Triângulo Mineiro. Apresentação do Hospital Escola da UFTM [Internet]. Minas Gerais, Brasil; 2015 [Acesso em 18 jan, 2016]. Disponível em: http://www.ebserh.gov.br/web/hc-uftm/historia

20. Brasil. Ministério da Saúde; Secretaria de Atenção à Saúde. Política Nacional de Humanização. Formação e intervenção. Brasília: MS; 2010.

21. Gountas S, Gountas J, Soutar G, Mavondo F. Delivering good service: personal resources, job satisfaction and nurses customer (patient) orientation. J Adv Nurs. 2014;70(7):1553-63.

22. Campolina AG, Adami F, Santos JLF, Lebrão ML. A transição de saúde e as mudanças na expectativa de vida saudável da população idosa: possíveis impactos da prevenção de doenças crônicas. Cad Saúde Pública. 2013;29(6):1217-29.

23. DeLaney MC, Page DB, Kunstadt EB, Ragan M, Rodgers J, Wang HE. Inability of Physicians and nurses to predict patient satisfaction in the Emergency Department. West J Emerg Med. 2015;16(7):1088-93.

24. Fenton JJ, Jerant AF, Bertakis KD, Franks P. A national study of patient satisfaction, health care utilization, expenditures, and mortality. Arch Intern Med. 2012;172 (5):405-11.

25. Borges PRR, Bedendo J, Fernandes CAM. Epidemiological profile of deaths in renal replacement therapy and cost of treatment. Acta Paul Enferm. 2013;26( 5 ):472-7.

26. Acosta AM, Lima MADS. Frequent users of emergency services: associated factors and reasons for seeking care. Rev Latino Am Enfermagem. 2015;23(2):337-44.

27. Morais AS, Melleiro MM.A qualidade da assistência de enfermagem em uma unidade de emergência: a percepção do usuário. Rev Eletr Enf [Internet]. 2013 [citado 2015 jun.21];15(1):112-20. Disponível em: https://www.fen.ufg.br/fen_revista/v15/n1/pdf/v15n1a13.pdf

28. Schmidt SMS, Müller FM, Santos E, Ceretta OS, Garlet V, Schmitt S. Análise da satisfação dos usuários em um hospital universitário. Saúde Debate. 2014;38(101):305-17.

29. Lloyd H, Jenkinson C, Hadi M, Gibbons E, Fitzpatrick R. Patient reports of the outcomes of treatment: a structured review of approaches. Health Qual Life Outcomes. 2014;12:5.

30. Paes NA, Silva CS, Figueiredo TMRM, Cardoso MAA, Lima JO. Satisfação dos usuários hipertensos com os serviços da rede de atenção primária no Brasil: um estudo de validação. Rev Panam Salud Publica. 2014;36(2):87-93.

31. Levandovski PF, Lima MADS, Acosta AM. Patient satisfaction with nursing care in an emergency service. Invest Educ Enferm. 2015;33(3):473-48.

32. Lima CA, Santos BT, Andrade DL, Barbosa FA, Costa FM, Carneiro JA. Qualidade dos prontos-socorros e prontos-atendimentos: a satisfação dos usuários. Einstein. 2015;13(4):587-93. 